\title{
Peculiarities of successional processes taking place in artificial phytocenoses on the Kuzbass coal mining dumps
}

\author{
Tatiana Lamanova, Natalia Sheremet", Vladimir Doronkin \\ Central Siberian Botanical Garden, of SB RAS, 630090 Novosibirsk. Russia
}

\begin{abstract}
The article presents results of the long-term studies of the structure and production of agrophytocenoses, established on the coal mining dumps in the Kuznetsk basin forest steppe zone. Agrophytocenoses were established on the leveled dumps by seeding grasses and legumes. Another set of control agrophytocenoses was established by the same technic on zonal soil. Seeds were provided by the laboratories of the Central Siberian Botanical Garden SB RAS, Novosibirsk. After 30 yrs of observations it was found that agrophytocenoses on the coal mining dumps did not have initial stage, as well as stage of spontaneous species invasion. Elimination of Trifolium pratense and Arrhenatherum elatius from coal mining dumps phytocenoses took place 3-4 yrs later than from agrophytocenoses on zonal soils. Species did not eliminate totally, but remained in communities with increased or decreased relative abundances. Significant number of species displayed fluctuation, rather than succession in course of 30 yrs development on the coal mining dumps. These phytocenoses It was also found that agrophytocenoses on the coal mining dumps have high long-term production potential.
\end{abstract}

\section{Introduction}

Modern researches are focused on vegetation successions due to economic activity $[1,2,3$, 4], and in particular due to open mining of fossil fuel etc. Kuznetsk coal deposit is the biggest one in Russia, both in estimated coal reserves and coal mining. Pit and dump complexes, resulting from the open mining, occupy vast areas in the region, and their revegetation goes slowly. It results in changed regional hydrological regime, contamination of the environment, increased erosion, decreased biodiversity and human health hazard. Restoration of disturbed lands by biological methods is possible by the establishing artificial sylvi- or agrophytocenoses. The latter can be used as agricultural areas, i.e. for hay-making and pastures, as well as recreational areas.

In 1989, by the request of Kuzbassrazresugol concern, we initiated agrophytocenoses establishing on the coal mining dumps, containing bedrock of different geological age, without addition of water-retaining layer and fertile soil layer, without any mineral or organic fertilization, as well as microbial preparations.

\footnotetext{
* Corresponding author: nsheremet@yandex.ru
} 


\section{Methods and conditions of the study}

The study was carried out on the coal mining dumps of Listvyansky mine (N53.674, E86.961) in the forest-steppe zone $15 \mathrm{~km}$ to the south-west of Novokuznetsk, Kemerovo region, Russia.

The local climate is continental with the day temperature sum above $10^{\circ} \mathrm{C}$ about 1800 $1900^{\circ} \mathrm{C}$. Annual precipitation is in average $450-600 \mathrm{~mm}$, with a snow cover in winter reaching 30-150 $\mathrm{cm}$. Prior to disturbance by the open mining leached and podzolised chernozems prevailed in the area. Surface mining resulted in the formation of coal mining dumps. Depending on the relative age of the bedrock, we distinguished two groups of dumps. Shallow coal deposits resulted in dumps of the Quaternary sediments, consisting of potentially fertile loesslike loams. Deep coal deposits resulted in dumps of Permian sediments, consisting of argyllites, aleurolites and sands. Granulometrically the sediments can be classified as substrates non-feasible for biological remediation [5].

On the thoroughly leveled dumps, composed by the Quaternary and Permian sediments, of the Listvyansky mine one or several species of grasses and legumes were sawn in July 1989-1990 on 100 ha. Establishment of the sustainable vegetation cover on lands, disturbed by surface mining, is possible due to the large assortment of seed bank and living plants collection, accrued over many years by researchers of the plant introduction laboratories of the Central Siberian Botanical Gardens of the Siberian Branch of the Russian Academy of Sciences. To create sustainable agrophytocenoses on the coal mining dumps we used the following species: common melilot (Melilotus officinalis (L.) Pall.), red clover (Trifolium pratense L.), hybrid clover (T. hybrydum L.), alfalfa (Medicago sativa L.), sainfoins (Onobrychis arenaria (Kit.) DC.), Cock's-foot (Dactylis glomerata L.), crested wheatgrass (Agropyron cristatum (L.) Beauv.), smooth brome (Bromopsis inermis (Leyss.) Holub), meadow fescue (Festuca pratensis Huds.), tall fescue (F. arundinacea Schreb.), tall oatgrass (Arrhenatherum elatius (L.) J. et C. Presl), Timothy grass (Phleum pratense L.), black bentgrass (Agrostis gigantea Roth. s. 1.).

Conventional geobotanical methods were used to study the agrophytocenoses [6-9]. Starting in the second year of agrophytocenoses' development, every year (1990-2004, 2013 гг.) in July-early August we collected the species-specific aboveground phytomass (4 replicates from each study site) to estimate phytomass production by each plant species and its contribution into the total community production. Overall 428 phytomass samples were collected.

\section{Results and discussion}

Reseearch on vegetation succession is not only theoretically interesting and challenging, but it is also of big practical significance. Succession is defined as a season-independent, directed and continuous sequence of emergence and disappearance of species in a given habitat [10]. According to T.A. Rabotnov [11], successions in plant communities started by sewing mixed seeds on the zonal soil are classified as secondary revegetation successions. Successions on the coal mining dumps, composed of Permian sediments, are classified as primary successions as they are taking place on substrates devoid of soil per se. Successions on the coal mining dumps, composed of Quaternary sediments, can be classified as primary ones, but only conditionally, as small amount of roots, rhizomes and seeds can enter the substrate during surface mining.

B.M. Mirkin and T.G. Gorskaya [9] by studying grass mixtures development in different zones of Bashkiriya distinguished three successional stages in fogger crops agrophytocenoses development on zonal soils. 
1. The initial stage dominated by explerents. The latter can be weeds or ruderal species. The stage usually lasts for 1-2 years and may not be very well pronounces in case of the high rate of seeds sawn.

2. The stage dominated by cultural crops. N.M. Dainenko and A.R. Matveev [14] revealed that on the zonal soil types this stage begins with elimination of the seeded species and lasts till perennial components are apparently stabilized. The production stage lasts for 1-2 or even 10 years and more.

3. The stage of ruderal species invasion followed by introduction of meadow and steppe species. The plant community is gradually enriched and getting closer in richness to the natural communities.

The longevity of the second stage is determined by the compliance between the edaphic and climatic requirements of the species used and by the risk of introducing some spontaneous species, better than cultural crops adapted to the local environment. According to the ratio of these factors three levels of potential longevity can be distinguished: high (30 and more years), moderate (10 years and more) and low (3-5 years). The moderate longevity was found to be common for mixed grasses and herbs crop.

Our long-term studies of vegetation dynamics in mono- or mixed crops on the coal mining dumps in the Kuzbass region showed that the regularities, commonly observed in artificial phytocenoses on zonal soils, were not always apparent on the coal mining dumps over the study period.

The initial successional stage in the agrophytocenoses was absent. The $1^{\text {st }}$ and the $2^{\text {nd }}$ years of phytocenoses' development had $80-97 \%$ of the aboveground phytomass produced by seeded grasses and legumes over the entire time span of the study. As an example let us consider the tall fescue phytocenoses (Fig. 1):

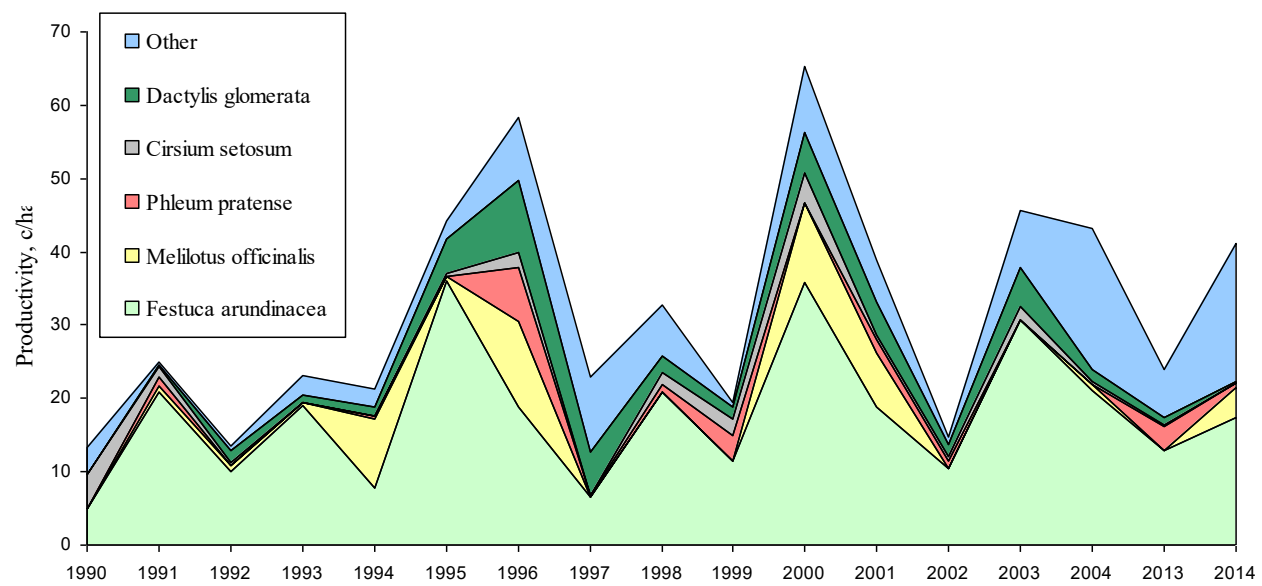

Fig. 1. Aboveground phytomass production (centner/ha) and species composition in the Festuca arundinaceae phytocenoses on the coal mining dumps in the forest-steppe of the Kuznetsk basin, Russia.

Elimination of such species as Trifolium pratense and Arrhenatherum elatius from agrophytocenoses grown on the coal mining dumps was found to occur 3-4 years later as compared with the agrophytocenoses, developed on the zonal soils. The species were found to be present during all the time, albeit at increased or decreased relative abundance. Optimal years resulted in increased abundance of the species, upregulating them to codomination [14]. This phenomenon was found to be true for all the species seeded on the coal mining dumps in the Kuznetsk basin [10]. Therefore, the artificial plant communities that we established function as polydominant meadows. 
In plant communities initiated by seed mixtures on the zonal soils successional changes can be observed during 10-20 years, whereas in communities, seeded on the coal mining dumps, most of plant species showed only fluctuation changes during 30 and more years. Thus the long-term observations on the structure and production of agrophytocenoses, established on the leveled coal mining dumps in the forest-steppe zone of the Kuznetsk baisin showed that such communities have high potential of productive longevity.

This high productive longevity results from the peculiarities of the ecotope, the correct choice of the plant species to use, the intensity and type of land use, and, most importantly, plant species potentials, our knowledge about which being rather limited. Besides, the possibility for diasporas to enter from external areas is impeded.

Our research showed that alongside the main benefit of low cost of such restoration technology, establishment of artificial phytocenoses on lands disturbed by surface coal mining in the Kuznetsk basin has the following advantages as well:

1) the vegetation cover restoration is possible not only on dumps, composed of Quaternary sediments, but also on dumps composed of Permian sediments, previously believed to be unfavourable for such restoration;

2) starting from $3^{\text {rd }}$ or $4^{\text {th }}$ years of development the plant communities can be used for hay-making and partially for grazing, their productivity equaling or even exceeding the one of the watershed natural meadows existing in the area prior to disturbance;

3) plant communities are characterized by high species richness, that, on the one hand, determined their sustainability, and, on the other hand, is of independent value for the restoration of ecosystem functions and services.

\section{References}

1. A.A. Titljanova, A.D. Sambuu, Succession in grasslands (SB RAS, Novosibirsk, 2016)

2. L. Huang, P. Zhang, Y. Hu, Y. Zhao, Global Ecol.Cons., 4 (2015)

3. J.F. Qu, S.L. Zhang, K. Wang, G. Li, N.S. Bu, Legislation, Technology and Practice of Mine Land Reclamation (London, 2015)

4. T.Z. Wang, X.D. Huang, Y.Y. Bao, X.R. Gan, Legislation, Technology and Practice of Mine Land Reclamation (London, 2015)

5. State Standard of the USSR. Protection of nature and lands. Classification of surface mining rocks and substituting substrates for the biological recultivation of lands (GOST 17.5.1.03.-86, 1987)

6. A.A. Korchagin, E.M. Lavrenko, Field Geobotany (M.-St.-P., 1976)

7. A.V. Kuminova, The vegetation of the Altai (USSR AS Pbs., Novosibirsk, 1960)

8. Cenopopulations of plants. Main concepts and structure (M, Nauka Pbs., 1976)

9. R. Whittacker, Communities and ecosystems (M, Progress Pbs., 1980)

10. Y.A. Pesenko, Principles and methods of the quantitative analysis in faunistic studies (M, Nauka Pbs, 1982)

11. M. Begon, G. Harper, C.R. Townsend, Ecology: Individuals, Populations, Ecosystems (M, Mir Pbs., 1989)

12. T.A. Rabotnov, Experimental phytocenology (M, Moscow University Pbs., 1987)

13. B.M. Mirkin, T.G. Gorskaya, Biol. Sci., 1 (1989)

14. N.M. Dainenko, N.M. Matveev, Dynamics of cenopopulations (M, 1985)

15. T.G. Lamanova, Plant resources, 34, 3 (1998) 